\title{
UJI TOKSISITAS FRAKSI n-HEKSAN DAUN BERUWAS LAUT (Scaevola taccada (Gaertn.) Roxb.) DENGAN METODE BRINE SHRIMP LETHALITY TEST
}

\author{
Rahmawati, Sitti Amirah, Andi Sulfika \\ Fakultas Farmasi Universitas Muslim Indonesia \\ Email : ningsihrahmawati@yahoo.com
}

\begin{abstract}
Research of effect toksisitas of $n$-heksan faction of the beruwas laut (Scaevola taccada (Gaertn.)Roxb.) leaf at prawn larva of Artemia salina Leach have been done as a mean to determine potency of toksisitas and value of $L C_{50}$ beruwas laut (Scaevola taccada (Gaertn.)Roxb.) leaf. As control used n-heksan. Before treatment, prawn egg of Artemia salina Leach incubated at some stage and after 48 hours prawn larva of Artemia salina Leach are ready to given treatment. Hereinafter n-heksan faction of beruwas laut (Scaevola taccada (Gaertn.)Roxb.) leaf with concentration 0,$1 ; 1 ; 10 ; 100 \mu \mathrm{g} / \mathrm{ml}$ in sea water enhanced 10 prawn larvas. For control, done same treatment. Perception done after 24 hours treatment by counting dead prawn larva. Result of perception indicate that value of $L C_{50} n$-heksan faction of beruwas laut (Scaevola taccada (Gaertn.)Roxb.) leaf 4,17 $\pm 2,59 \mu \mathrm{g} / \mathrm{ml}$. So that can be expressed that $n$-heksan faction of beruwas laut (Scaevola taccada (Gaertn.)Roxb.) leaf have potency as anticancer, this matter is based by standard of Meyer (1982) expressing that a natural materials compound have potency of anticancer if value of $L C_{50}<1000 \mu \mathrm{g} / \mathrm{ml}$.
\end{abstract}

Key word : Toksisitas Test, Scaevola taccada (Gaertn.)Roxb, Brine Shrimp Lethality Test

\section{PENDAHULUAN}

Keanekaragaman hayati yang ada di bumi ini tak hanya digunakan sebagai bahan pangan atau hiasan, tetapi juga bermanfaat sebagai bahan untuk mengobati berbagai penyakit. Tanaman yang ada, terutama yang tumbuh di Indonesia dikenal sebagai bahan yang ampuh sebagai obat dan digunakan sebagai bahan obat tradisional. Belakangan ini telah banyak dilakukan penelitian mengenai tanaman yang berpotensi sebagai obat tradisional. Salah satu tanaman tradisional yang diteliti adalah Beruwas Laut (Scaevola taccada (Gaertn.) Roxb.) yang mengandung glukosid jenis skaevolin dan satu lagi jenis glukosid lain dari seluruh bagian tumbuhan ini, juga mengandung alkaloid, fenol, saponin, steroid dan flavanoid (Ong, 2004 ; Soo, 2009 ; Rauf, 2012) sebagai obat infeksi mata, menyembuhkan gangguan 
Uji Toksisitas Fraksi n-Heksan Daun Beruwas Laut Dengan Metode Brine Shrimp Lethality Test

pencernaan, malaria, batuk dan flu.

Sampai saat ini belum banyak penelitian yang mengupas tentang toksisitas beruwas laut (Scaevola taccada (Gaertn.) Roxb.) (Wardini, 2011).

Uji toksisitas dimaksudkan untuk memaparkan adanya efek toksik dan untuk meneliti batas keamanan penggunaan suatu tanaman sebagai obat tradisional (Cassaret and Doull's, 1991). Suatu ekstrak dinyatakan bersifat toksik menurut metode Brine Shrimp Lethality Test jika memiliki Lethal Concentration ( $\mathrm{LC}_{50}$ ) kurang dari $1000 \mu \mathrm{g} / \mathrm{ml}$ (Meyer, 1982). Jika hasil uji Brine Shrimp Lethality Test menunjukkan bahwa ekstrak tumbuhan bersifat toksik maka dapat dikembangkan ke penelitian yang lebih lanjut berupa penelitian sitotoksik tumbuhan sebagai pengembangan obat antikanker (Rosenda, 2009).

\section{METODE PENELITIAN}

\section{A. Alat dan Bahan}

Alat-alat yang digunakan dalam penelitian ini adalah aerator (Life $Q_{3}$ ), alat-alat gelas, lampu, mikropipet (Gilson), Rotavapor (IKA rv 10), seperangkat alat maserasi, timbangan kasar (Triple Beam), timbangan analitik (Ohaus) dan vial.
Bahan-bahan

yang digunakan dalam penelitian ini adalah air laut, aquadest, ekstrak n-heksan beruwas laut (Scaevola taccada (Gaertn.) Roxb.), etanol 70 $\%$, n-heksan, ragi, dan telur udang (Artemia salina Leach).

\section{B. Prosedur Kerja}

\section{Penyiapan Simplisia}

a. Pengambilan sampel

Sampel daun beruwas laut (Scaevola taccada (Gaertn.) Roxb.) diambil dari Cappa Batue Kelurahan Wiring Tasi Kecamatan Suppa Kabupaten Pinrang Provinsi Sulawesi-Selatan.

b. Pengolahan sampel

Sampel daun beruwas laut (Scaevola taccada (Gaertn.) Roxb.) dicuci bersih dengan menggunakan air yang mengalir, kemudian dipotong kecil-kecil dan dikeringkan dengan cara diangin-anginkan dan tidak terkena sinar matahari langsung.

\section{c. Ekstraksi Sampel}

1) Ekstraksi secara maserasi dengan pelarut etanol 
Uji Toksisitas Fraksi n-Heksan Daun Beruwas Laut Dengan Metode Brine Shrimp Lethality Test

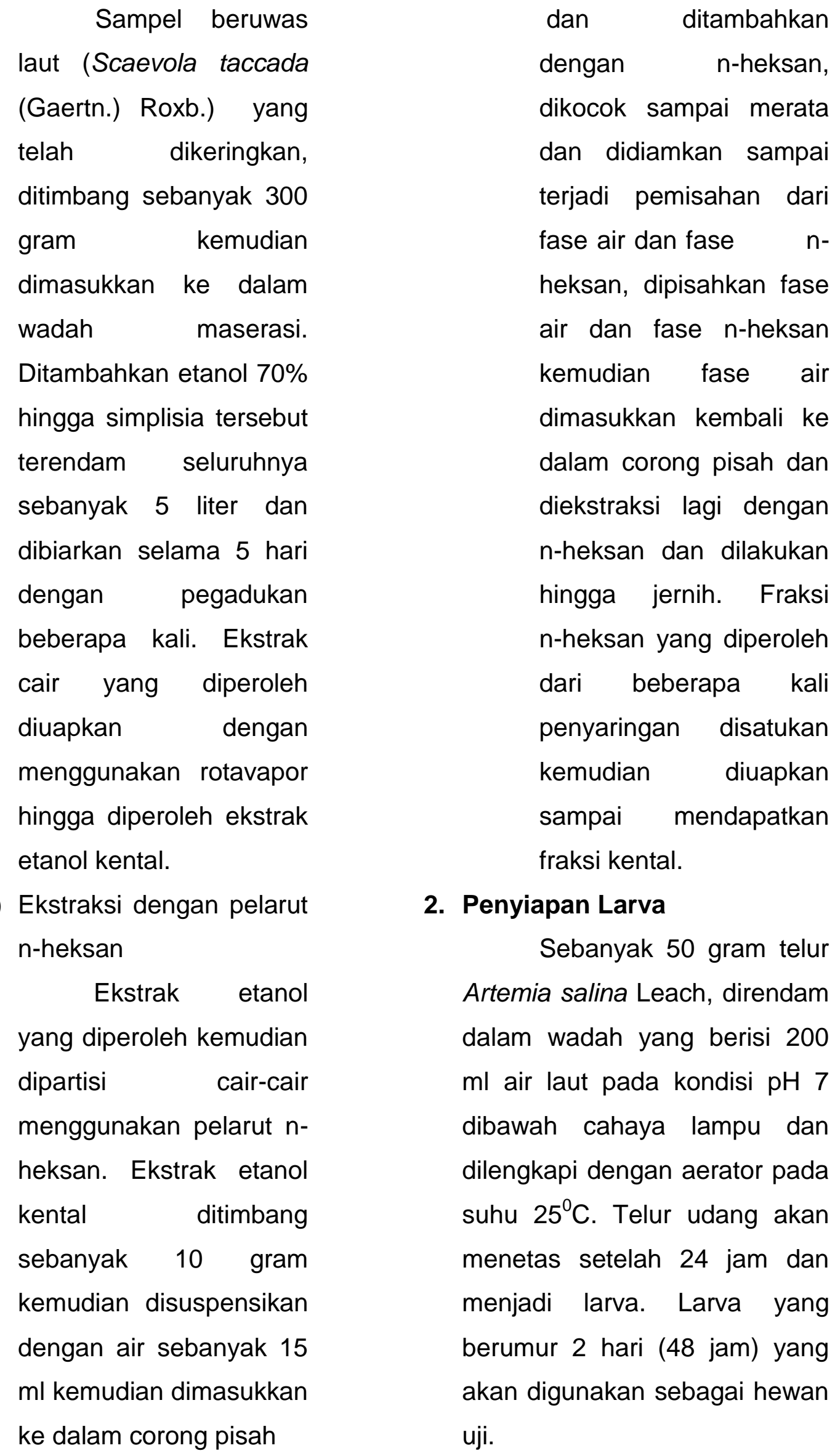


Uji Toksisitas Fraksi n-Heksan Daun Beruwas Laut Dengan Metode Brine Shrimp Lethality Test

3. Pelaksanaan Pengujian

Fraksi n-heksan kental ditimbang sebanyak $100 \mathrm{mg}$ dilarutan dengan $\mathrm{n}$-heksan 10 $\mathrm{ml}$ sehingga diperoleh konsentrasi $100 \mathrm{mg} / 10 \mathrm{ml}$ sebagai larutan persediaan (stok). Dari sediaan tersebut dipipet 0,$1 ; 1 ; 10$; dan 100 $\mu \mathrm{l} / \mathrm{ml}$, selanjutnya $\mathrm{n}$-heksan diuapkan. Untuk kontrol yaitu pelarut $\mathrm{n}$-heksan $10 \mu \mathrm{l} n$ heksan dalam $10 \mathrm{ml}$ air laut, kemudian dipipet 0,$1 ; 1 ; 10$; $100 \mu \mathrm{l} / \mathrm{ml}$ ke dalam masingmasing vial.

Ke dalam masing-masing vial yang berisi fraksi $n$-heksan dan kontrol dengan konsentrasi 0,$1 ; 1 ; 10 ; 100 \mu \mathrm{g} / \mathrm{ml}$ ditambahkan $5 \mathrm{ml}$ air laut, lalu dimasukkan 10 ekor larva udang Artemia salina Leach. Ke dalam tiap vial ditambahkan 1 tetes suspensi ekstrak ragi (3 $\mathrm{mg}$ dalam $5 \mathrm{ml}$ air laut) sebagai sumber makanan. Dicukupkan volumenya sampai $10 \mathrm{ml}$. Vialvial uji kemudian disimpan di tempat yang cukup mendapat sinar lampu. Setelah 24 jam dilakukan pengamatan terhadap jumlah larva yang mati. Untuk tiap sampel dan kontrol dilakukan pengulangan sebanyak 3 kali.

\section{HASIL PENELITIAN}

Tabel 1. Data Hasil Pengamatan Kematian Larva Udang Artemia salina Leach setelah 24 Jam Perlakuan

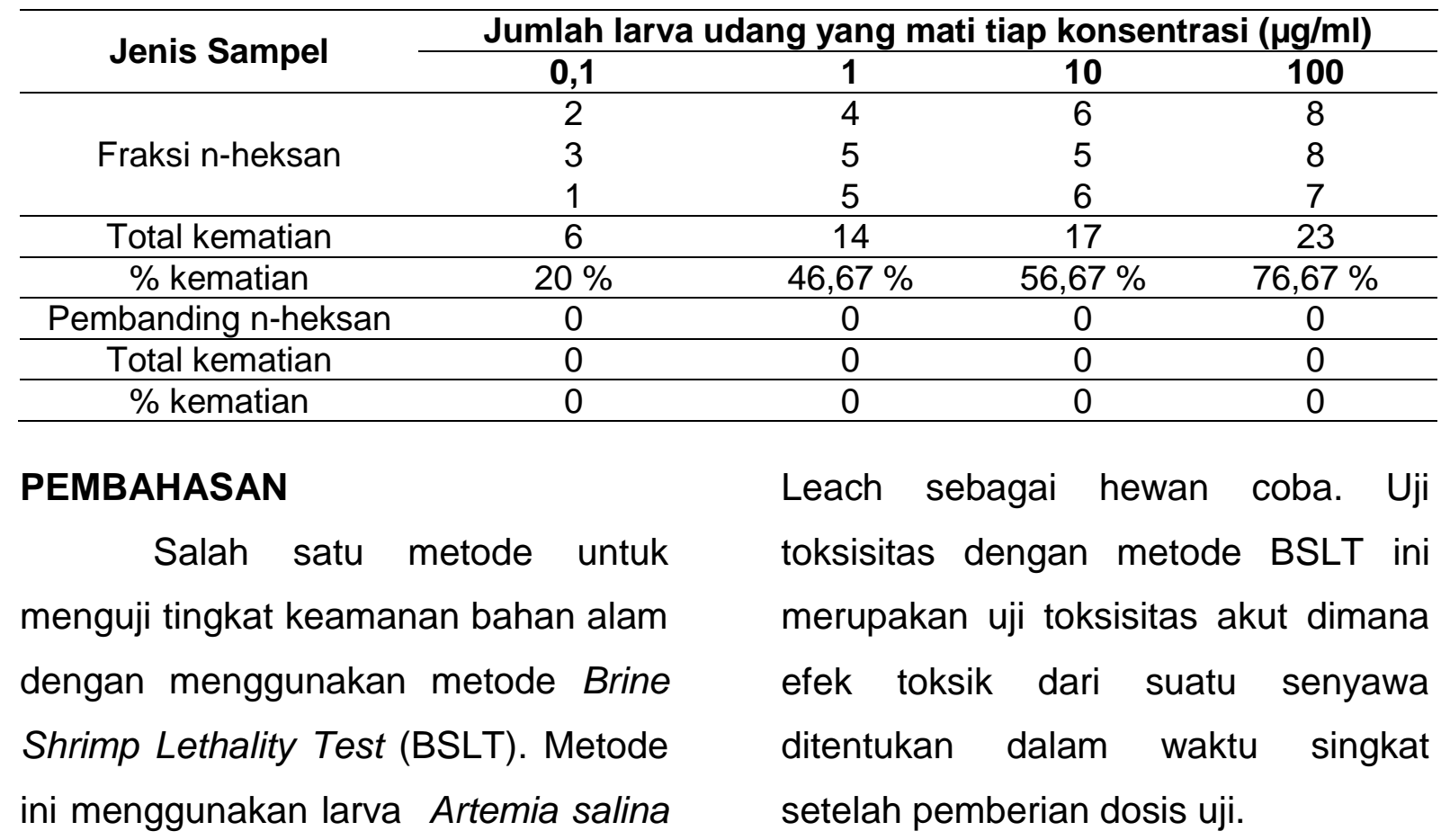


Uji Toksisitas Fraksi n-Heksan Daun Beruwas Laut Dengan Metode Brine Shrimp Lethality Test

Metode ekstraksi yang digunakan adalah maserasi karena tekstur tanaman yang digunakan lunak. Maserasi merupakan cara penyarian sederhana, yang dilakukan dengan cara merendam serbuk dalam cairan penyari selama beberapa hari pada temperatur kamar dan terlindung dari sinar matahari langsung. Metode maserasi digunakan untuk menyari simplisia yang mengandung zat aktif atau komponen kimia yang mudah larut dalam cairan penyari. Setelah maserasi, ekstraksi kemudian dilanjutkan dengan partisi cair-cair untuk memisahkan komponen kimia berdasarkan tingkat kepolaran.

Pada penelitian ini digunakan variasi konsentrasi fraksi $\mathrm{n}$-heksan daun beruwas laut (Scaevola taccada (Gaertn.)Roxb.) 0,1:1:10: dan 100 $\mu \mathrm{g} / \mathrm{ml}$ dimaksudkan untuk melihat variasi respon yang diberikan, bila nilai $\mathrm{LC}_{50}<1000 \mu \mathrm{g} / \mathrm{ml}$ dinyatakan bersifat toksik dan memiliki potensi antikanker. Kemudian dibandingkan dengan $\mathrm{n}$ heksan pada konsentrasi yang sama. Penggunaan pembanding pelarut $\mathrm{n}$ heksan dimaksudkan untuk mengetahui apakah respon kematian hewan uji disebabkan oleh komponen kimia yang terkandung atau pelarut yang digunakan.
Fraksi n-heksan daun beruwas laut (Scaevola taccada (Gaertn.)Roxb) diujikan pada hewan uji larva udang Artemia salina Leach yang berumur 48 jam, karena pada umur tersebut Artemia salina Leach mengalami pertumbuhan yang cepat sehingga diasumsikan pertumbuhan sel yang abnormal. Selain itu, usia larva udang 48 jam telah memiliki sistem pencernaan yang lengkap dan telah terlepas dari cangkang telur.

Selama proses penetasan, kondisi ditentukan dengan $\mathrm{pH}$ 7-8 dimana Artemia salina Leach hidup optimal pada $\mathrm{pH}$ tersebut. Penggunaan aerator dalam penetasan larva udang dimaksudkan untuk membantu sirkulasi udara dalam air dan diberi pencahayaan untuk menjaga suhu sehingga merangsang penetasan telur.

Setelah perlakuan 24 jam, dihitung jumlah larva udang yang mati. Mekanisme kematian larva berhubungan dengan hubungan fungsi senyawa yang terkandung dalam daun beruwas laut (Scaevola taccada (Gaertn.) Roxb.) berupa glikosid jenis skaevolin dan satu lagi jenis glikosid lain dari seluruh bagian tumbuhan ini, juga mengandung alkaloid, fenol, saponin, steroid, dan flavonoid yang 
Uji Toksisitas Fraksi n-Heksan Daun Beruwas Laut Dengan Metode Brine Shrimp Lethality Test

menghambat daya makan larva. Cara kerja senyawa tersebut denngan bertindak sebagai stomach poisoning atau racun perut. Oleh karena itu, bila senyawa-senyawa inimasuk ke dalam tubuh larva, alat pencernaannya akan terganggu.

Hasil dari analisis probit menunjukkan nilai $\mathrm{LC}_{50}$ dari fraksi $\mathrm{n}$ heksan daun beruwas laut (Scaevola taccada (Gaertn.)Roxb.) adalah 4,17 \pm $2,59 \mu \mathrm{g} / \mathrm{ml}$. Hasil ini menunjukkan bahwa fraksi $n$-heksan daun beruwas laut (Scaevola taccada (Gaertn.)Roxb.) bersifat toksik dan memiliki potensi sebagai antikanker, jika dibandingkan dengan standar Meyer (1982) bahwa suatu senyawa bahan alam dikatakan memiliki potensi antikanker jika nilai $\mathrm{LC}_{50}<1000 \mu \mathrm{g} / \mathrm{ml}$.

\section{KESIMPULAN}

Hasil penelitian dan hasil analisis probit disimpulkan bahwa fraksi n-heksan daun beruwas laut (Scaevola taccada (Gaertn.)Roxb.) bersifat toksik dan memiliki potensi sebagai antikanker dengan nilai $\mathrm{LC}_{50}$ $4,17 \pm 2,59 \mu \mathrm{g} / \mathrm{ml}$.

\section{DAFTAR PUSTAKA}

Alam, G. 2002. BST Sebagai Bioassay Dalam Isolasi Senyawa Bioaktif dari Bahan Alam. Majalah Farmasi dan Farmakologi, vol 6.

Casarett, L.J., and Doul J., 1991. Toxicology, The Basic Sceine of
Poison, First Edition, Mac Millan Publishing, Co, Inc, New York.

Ditjen POM., 1986. Sediaan Galenik. Jakarta: Departemen Kesehatan RI

Gandjar, I.G., dan A. Rohman, 2007. Kimia Farmasi Analisis. Yogyakarta : Pustaka Pelajar.

LIPI,2011.Hasilldentifikasi/Determinasi Tumbuhan.(Laporan Penelitian No.1178/IPH.1.02/if.8/VIII/201 1). Lembaga IImu Penelitian Indonesia : Cibinong.

Loomis, T.A., 1978, Toksikologi Dasar, edisi III, penerjemah Imono Argo, IKIP Semarang Press.

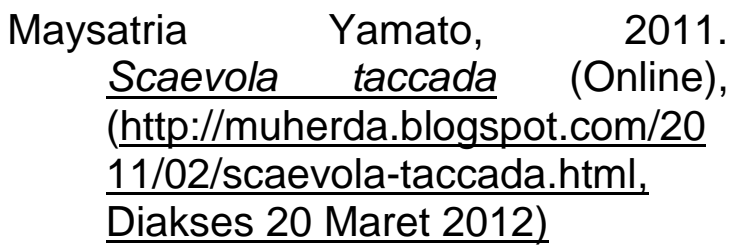

McLaughlin, J.E., 1991. A Blind Comparison of Simple Benzch Top Bioassay and Human Tumor Cell Cytotoxicities as Antitumor Prescreens, Natural Product Chemistry. Elsivier, Amsterdam.

Meyer, B.N., Ferrigni, N. R., Putman, J. E., Jacbsen, L. B., Nicols, D.E., and McLaughlin, J. L. 1982. Brine Shrimp : A Comvenient General Bioassay For Active Plant Constituent. Plant Medica.

Mudjiman, A. 1989. Udang Renik Air Asin. Brata Karya Aksara, Jakarta.

Mukono, H.J. 2005. Toksikologi Lingkungan. Airlangga University Press, Surabaya. 
Uji Toksisitas Fraksi n-Heksan Daun Beruwas Laut Dengan Metode Brine Shrimp Lethality Test

National Tropical Botanical Garden. 2011. Scaevola taccada (Online). http://ntbg.org/plants/scaevolatac cada/plantdetails.php.htm, Diakses 20 Maret 2012)

Ong Hean Chooi, 2004, Tumbuhan Liar : Khasiat Obat Dan Kegunaan

(Online),(http://www.scribd.com/d oc/64909444/Bio-Divers-It-As, Diakses 20 Maret 2012)

Priyanto. 2009. Toksikologi. Mekanisme, Terapi Antidotum dan Penilaian Resiko. Lembaga Studi dan Konsultasi Farmakologi (Leskonfi), Depok.

Rauf, Maryani. 2012. Aktivitas Antimikroba Ekstrak n-Heksan Daun Beruwas Laut (Scaevola taccada (Gaertn.)Roxb.) Dengan Metode KLT-Bioautografi. Fakultas Farmasi. Universitas Muslim Indonesia.

Ramadhani, Ahmad Nur. 2009. Uji Toksisitas Akut Ekstrak Etanol
Daun Sukun (Artocarpus altilis) Terhadap Larva Artemia Salina Leach Dengan Metode Brine Shrimp Lethality Test (BST). Fakultas Kedokteran. Universitas Diponegoro, Semarang.

Rosenda, E.H. Anandita dan Suhardjono. 2009. Uji Toksisitas Ekstrak Etanol Daun Kemangi (Ocimun sanctum Linn.) Terhadap Larva Artemia salina Leach Dengan Metode Brine Shrimp Lethality Test. Majalah Farmasi Indonesia, Semarang.

Soemirat, Juli dkk. 2009. Toksikologi Lingkungan. Gadjah Mada Uiversity Press, Yogyakarta.

Soo, S.Y. 2009. Medical Plants In Papua New Guinea. Western Pacific: WHO Press.

Wardini, T. H., 2011. Medicinal and Poisonous Plants (Online)(http://www.proseanet.or g/florakita/browser.php?docsid=7

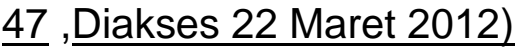

